\title{
Productivity and grain quality of various types of spring wheat depending on seeding rates and nutrition background on gray forest soil of the Pre-Kama Region of the Republic of Tatarstan
}

\author{
Farit Shaikhutdinov ${ }^{1}$, Marat Amirov ${ }^{1}$, Igor Serzhanov ${ }^{1 *}$, Razil Garaev $^{1}$, and Ahmet Akköprü ${ }^{2}$ \\ ${ }^{1}$ Kazan State Agrarian University, 420015 Kazan, Republic of Tatarstan, Russia \\ ${ }^{2}$ Van Yüzüncü Yil University, Van, Turkey
}

\begin{abstract}
The results of two-year (2018-2019) studies on the effect of various seeding rates and nutritional backgrounds on the yield and grain quality of two types of spring wheat - soft wheat and emmer wheat (spelt) - are considered. The agrochemical characteristic of the gray forest soil of the experimental plot is as follows: the humus content in the layer of 0-20 cm was 2.9-3.4\% (Tyurin method), mobile phosphorus amount was 176-241 mg, exchange potassium amount was 77-109 mg/kg of soil (Kirsanov method). The degree of saturation with bases was 85.2-87.7 \%, the $\mathrm{pH}$ of the salt extract was 5.6-5.8. Agrometeorological conditions of 2018-2019, on the whole, met the requirements for early spring crop seeding, HTC (hydrothermal coefficient) was 0.85-1.2. Two levels of mineral nutrition were studied in the experiment (natural background, without fertilizing, NRK for the planned grain yield of $3 \mathrm{t} / \mathrm{ha}$ ), four seeding rates against each nutrition background: 4, 5, 6 and 7 million germinating seeds per 1 ha. The seedling completeness in both types of wheat over an average of 2 years depended on the seeding rate, regardless of the background of nutrition. In soft wheat of Ulyanovskaya 105 variety, against a natural background, with an increase in the sowing rate from 4 to 7 million germinating seeds per ha, the seedling completeness decreased and amounted to from 82.5 to $76.3 \%$, in spelt, it was $84.7-78.6 \%$. On a fertilized ground it was, respectively, 83.4-78.0 and 84.1-77.6\%. Good preservation of plants in both types of wheat from the number of sown seeds and seedlings was noted when the sowing rate was reduced from 7 to 4 million: without fertilizer 82.6-88.5\% in common wheat and 83.5-90.4\% of spelt. On a fertilized ground it amounted, respectively, to 84.3-90.5 and 86.5-92.3\%. Changes in nutritional background by introducing calculated doses of mineral fertilizers for all options with seeding rates on average for 2018-2019 yielded an increase in soft wheat by 0.94 tons of grain per hectare and by 0.61 tons of spelt. The highest conversion efficiency of fertilizers at a sowing rate of 6 million in common wheat was $8.1 \mathrm{~kg}$ of grain per $1 \mathrm{~kg}$ of a.a., for spelt at a sowing rate of 4 million the figure was $5.6 \mathrm{~kg}$ per $1 \mathrm{~kg}$ of a.a.
\end{abstract}

\section{Introduction}

Increasing food grain production is one of the main tasks in the development of agriculture in the Russian Federation and in the Republic of Tatarstan. In 2019, spring wheat sowings occupied 430 thousand ha. The gross grain harvest of spring wheat amounted to 2 million 236 thousand tons, and the yield of 3.27 tons/ha. Despite the obvious successes, there are unresolved problems in the production of food wheat: crop stability has not yet been achieved (2.54 t/ha in 2016; 2.67 t/ha 2017; 2.75 t/ha 2018); a significant part of grain handed over to the state in quality does not meet the requirements of GOST, its cost price remains high while the level of profitability remains low $[1,2,7]$.

The experience of the leading farms of the republic and research institutions shows that the soil and climatic conditions of the republic allow obtaining high yields of spring wheat of good quality and increase the economic efficiency of the production of food grain of this crop $[3,6]$.

It is known that the most important condition for obtaining high yields of good quality is the use of new highly productive varieties and further improvement of the technology for their cultivation. However, the potential capabilities of varieties and the effectiveness of various progressive methods of cultivating any crops can be fully realized only with the optimum density of the stand, which is mainly determined by the seeding rate $[4,5,8]$.

In spring wheat, characterized by weak stooling on different backgrounds of fertilizers when more intensive varieties are introduced into the production, the seeding rate undergoes certain changes [9-11]. In this regard, we conducted studies to identify optimal seeding rates for different nutritional backgrounds: recognized varieties of spring Ulyanovskaya 105 soft wheat, and Runo spelt on

* Corresponding author: igor.serzhanov@mail.ru 
gray forest soils of the Pre-Kama Republic of the Republic of Tatarstan.

The aim of the research was to establish optimal seeding rates for recognized varieties of spring Ulyanovskaya 105 soft wheat and Runo spelled wheat on various nutrition backgrounds, providing a more complete realization of the potential of wheat species.

\section{Conditions and Methods of Research}

The studies were conducted in 2018-2019 in field and laboratory experiments. Field experiments involved gray-forest soil on the experimental site of the Department of Plant Production of the Kazan State Agrarian University in the Laishevsky municipal district of the Republic of Tatarstan. Analysis of soil and plant samples was carried out in the laboratories of the Department of Plant Growing of the Agronomy Faculty and in the laboratories of the Institute of Agrochemistry and Agrology of the Kazan SC of RAS.

The experiments were organized as follows:

I natural background - without fertilizers (control);

II background - estimated background for the planned grain yield of 3 tons per 1 hectare;

Against each nutrition background, four seeding rates 4 were tested: $4,5,6$ and 7 million germinating grains per 1 hectare. The experiments were repeated four times; the allocation of plots of different nutritional backgrounds was randomized, the seeding rates against each background were consistent. The total area of the plots is $60 \mathrm{~m}^{2}$, the accounting area was $50 \mathrm{~m}^{2}$.

The experiments were carried out on gray forest loamy soil with a humus content in the layer of $0-20 \mathrm{~cm}$ of 2.9-3.4 (Tyurin method), mobile phosphorus content was 176-241 mg, exchange potassium content was $77-109 \mathrm{mg} / \mathrm{kg}$ of soil (Kirsanov method), the amount of absorbed bases was $26-27.3 \mathrm{mg}$ per $100 \mathrm{~g}$ of soil. The degree of saturation with bases was $85.2-87.7 \%$, the $\mathrm{pH}$ of the salt extract was 5.6-5.8.

The experiments were set up after winter rye, which was cultivated on fertilized clean fallow land. The treatment of the fall-plowed land with primary tillage was carried out in the third decade of August. The amount of fertilizers was calculated by the balance method and applied by presowing cultivation in the following doses: II background - $\mathrm{N}_{86-90} \mathrm{P}_{19-34} \mathrm{~K}_{6-50}$. Sowing was carried out after presowing cultivation with the first-class seeds cultivated with ZhUSS-2, to a depth of 4-5 cm with an SN-16 seeder attached to an MTZ-80 tractor. Actual seeding rates deviated from the calculated by $1.5-3.0 \%$.

Crop care was carried out in accordance with the requirements of the progressive technology of spring wheat cultivation: rolling after sowing; harrowing before germination; treatment of crops with Puma Super herbicide (0.8-1.0 1/ha); BI-58 Novyi agent (40\% EC) in the amount of $0.7-1.0 \mathrm{~kg}$ of per hectare was used against cereal aphids, leech and thrips; $0.5 \mathrm{~kg} / \mathrm{ha}$ of bayleton agent (20\% s.p.) or $250-0.4 \mathrm{~kg} / \mathrm{ha}$ of TILT together with $3 \mathrm{~kg} / \mathrm{ha}$ of cineb (80\% s.p.) were used against rust and powdery mildew. The experimental crops were harvested in the phase of full ripeness by a SAMPO-500 combine.
The meteorological conditions in 2018 were characterized by insufficient moisture and high temperature conditions in the initial periods of vegetation of the tested crops. In May, $21.8 \mathrm{~mm}$ of precipitation fell, which is $55.9 \%$ of the average annual norm, in June, it amounted to $34.4 \mathrm{~mm}$, or $60.7 \%$ of the norm in the second half of July (the norm is $52 \mathrm{~mm}$ ).

According to meteorological data, the vegetation period of 2019 was characterized as favorable both in temperature conditions and in the moisture supply of plants of the tested cultures in the process of growth and development. Precipitation in May was $173 \%$ of the average long-term norm, and the average air temperature was $3{ }^{\circ} \mathrm{C}$ higher than average values. In total, in June fell $58 \%$ of the precipitation norm. The average air temperature exceeded the norm by 2 degrees. In July, precipitation amounted to $83 \%$ of the norm with an average daily air temperature of $18.5^{\circ} \mathrm{C}$, which is 1 degree lower than the norm.

\section{Results and Discussion}

The formation of high and stable spring wheat yields is closely correlated with the number of full-fledged seedlings and, ultimately, with the optimal density of the plant stand. In the conditions of the Pre-Kama zone of the Republic of Tatarstan, the most important factor determining the optimal density of the stand is the biological characteristics of the wheat species and varieties. According to the biennial data (2018-2019), the best indicators of the state of crops according to the completeness of emergence of seedlings in spring wheat of Ulyanovskaya 105 variety with an increase in the seeding rate from 4 to 7 million on natural background, the completeness of seedlings decreased from 82.5 to $76.3 \%$ and from 83.4 to $78.0 \%$ on fertilized background. For spelt, the figures were 84.7-78.6 and 84.1-77.6, respectively (Table 1 ).

The influence of nutritional background on field germination was not clearly manifested. The density of the productive plant stand in the studied varieties was mainly determined by the seeding rate, but also depended on the field germination, the degree of tillering and the preservation of plants during the growing season.

On all nutritional backgrounds, the plant susceptibility of the studied species and varieties of spring wheat during the growing season increased with the thickening of crops. With an increase in the seeding rate from 4 to 7 million on average over 2 years against the background I, the survival rate of spring wheat plants of the Ulyanovskaya 105 variety decreased by $7.7 \%$; against the background II it was 6.4; for Runo spelt, the survival rates were 9.3 and 5.9, respectively.

The density of the productive plant stand in our experiments was also determined by the degree of tillering of plants. With an increase in the seeding rate from 4 to 7 million, the total and productive stooling of common wheat decreased. In particular, the productive stooling of the variety Ulyanovskaya 105 decreased from 1.15 to 1.0 over an average of 2 years on the unfertilized land and from 1.2 to 1.0 on the fertilized land, while a tendency to 
plentiful and long tillering was revealed in the Runo spelt which formed 750-1000 productive stems per $1 \mathrm{~m}^{2}$.

Table 1. Seedling completeness and preservation of plants of spring wheat species at different seeding rates and nutritional backgrounds (av. over 2018-2019)

\begin{tabular}{|c|c|c|c|c|c|c|}
\hline \multirow[t]{2}{*}{$\begin{array}{l}\text { Nutritional } \\
\text { background }\end{array}$} & $\underline{\widetilde{z}}$ & \multicolumn{2}{|c|}{ Full sprouts } & \multicolumn{3}{|c|}{$\begin{array}{c}\text { Preservation of plants to } \\
\text { full ripeness }\end{array}$} \\
\hline & 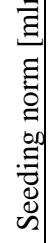 & 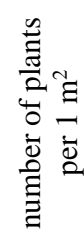 & 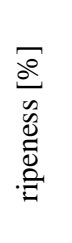 & 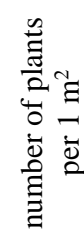 & 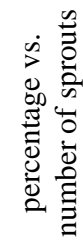 & 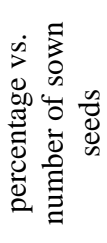 \\
\hline \multirow{5}{*}{$\begin{array}{l}\text { Natural } \\
\text { background } \\
\text { (control) }\end{array}$} & \multicolumn{6}{|c|}{ Ulyanovskaya 105 spring soft wheat } \\
\hline & 4 & 330 & 82.5 & 292 & 88.5 & 73.0 \\
\hline & 5 & 405 & 80.9 & 350 & 86.3 & 70.0 \\
\hline & 6 & 470 & 78.4 & 396 & 84.2 & 66.0 \\
\hline & 7 & 534 & 76.3 & 441 & 82.6 & 63.0 \\
\hline \multirow{4}{*}{$\begin{array}{l}\text { NPK estimated } \\
\text { for yielding } 3 \\
\text { tons of grain } \\
\text { per ha }\end{array}$} & 4 & 334 & 83.4 & 302 & 90.5 & 75.6 \\
\hline & 5 & 407 & 81.4 & 361 & 88.7 & 72.2 \\
\hline & 6 & 468 & 78.0 & 403 & 86.1 & 67.1 \\
\hline & 7 & 546 & 78.0 & 460 & 84.3 & 65.8 \\
\hline \multirow{5}{*}{$\begin{array}{l}\text { Natural } \\
\text { background } \\
\text { (control) }\end{array}$} & \multicolumn{6}{|c|}{ Runo emmer wheat (spelt) } \\
\hline & 4 & 339 & 84.7 & 306 & 90.4 & 76.6 \\
\hline & 5 & 409 & 81.8 & 359 & 87.8 & 71.8 \\
\hline & 6 & 472 & 78.7 & 403 & 85.4 & 67.2 \\
\hline & 7 & 550 & 78.6 & 459 & 83.5 & 65.6 \\
\hline NPK estimated & 4 & 336 & 84.1 & 310 & 92.3 & 77.5 \\
\hline for yielding 3 & 5 & 410 & 82.0 & 370 & 90.2 & 74.0 \\
\hline tons of grain & 6 & 475 & 79.2 & 420 & 88.4 & 70.0 \\
\hline per ha & 7 & 543 & 77.6 & 470 & 86.5 & 67.1 \\
\hline
\end{tabular}

With a decrease in the seeding rate from 7 to 4 million, productive stooling increased from 1.6 to 2.7 on the unfertilized background and from $1.67-2.76$ on the fertilized land. Due to the weak tillering of Ulyanovskaya
105 spring soft wheat, the density of the productive plant stand on both nutritional backgrounds increased with increasing seeding rates, and for the spelt - due to the tendency to strong tillering - the density of the productive plant stand did not depend on the nutrition background increased with a decrease in seeding rates from 7 to 4 million germinating seeds per 1 ha.

The environmental conditions were different depending on the characteristics of the year, nutrition background and seeding rates, and, therefore, the elements composing the crop and its grain harvest per unit area could be different (Table 2).

Changes in nutritional background by introducing calculated doses of mineral fertilizers had an impact on the yield of both types of spring wheat. For all options with seeding rates, on average over two years, the introduction of estimated doses of fertilizers for the Ulyanovskaya 105 variety averaged an increase of 0.94 tons per hectare, and 0.6 tons for emmer wheat (spelt).

The expediency of differentiating the seeding rates depending on the background of nutrition was revealed. The optimal seeding rate for Ulyanovskaya $105 \mathrm{soft}$ wheat on unfertilized (natural) background was 5 million seeds, against a fertilized background of 6 million germinating seeds per hectare. For spelt in both nutritional backgrounds, the optimal sowing rate was 4 million germinating seeds per hectare. On average, over 2 years at the optimum sowing rate of Ulyanovskaya 105, 2.62 tons were obtained per hectare against natural background, and 3.53 tons of grain per hectare against fertilized background. Emmer wheat (spelt) amounted to 2.42 and 3.22 tons of grain, respectively.

Table 2. Productivity of spring wheat species at different seeding rates and nutritional background (t/ha)

\begin{tabular}{|c|c|c|c|c|c|c|c|}
\hline \multirow{2}{*}{$\begin{array}{c}\text { Nutritional } \\
\text { background (A) }\end{array}$} & \multirow{2}{*}{$\begin{array}{l}\text { Seeding } \\
\text { norm [mln } \\
\text { ha] (B) }\end{array}$} & \multicolumn{2}{|c|}{ Years } & \multirow{2}{*}{$\begin{array}{l}\text { Average } \\
\text { biennial }\end{array}$} & \multicolumn{2}{|c|}{ Yield surplus } & \multirow{2}{*}{$\begin{array}{c}\text { Conversion efficiency } \\
\text { [kg a.a. fert., } \mathrm{kg} \text { of } \\
\text { grain] }\end{array}$} \\
\hline & & 2018 & 2019 & & seeding norm & $\begin{array}{c}\text { nutritional } \\
\text { background }\end{array}$ & \\
\hline \multicolumn{8}{|c|}{ Ulyanovskaya 105 spring soft wheat } \\
\hline \multirow{4}{*}{$\begin{array}{l}\text { Natural } \\
\text { background } \\
\text { (control) }\end{array}$} & 4 & 2.45 & 2.51 & 2.48 & - & - & - \\
\hline & 5 & 2.58 & 2.60 & 2.62 & 0.14 & - & - \\
\hline & 6 & 2.29 & 2.44 & 2.36 & -0.12 & - & - \\
\hline & 7 & 2.30 & 2.37 & 2.33 & -0.15 & - & - \\
\hline \multirow{4}{*}{$\begin{array}{l}\text { NPK estimated } \\
\text { for yielding } 3 \text { tons } \\
\text { of grain per ha }\end{array}$} & 4 & 3.24 & 3.30 & 3.27 & - & 0.79 & 5.5 \\
\hline & 5 & 3.32 & 3.43 & 3.38 & 0.11 & 0.76 & 5.3 \\
\hline & 6 & 3.45 & 3.61 & 3.53 & 0.26 & 1.17 & 8.1 \\
\hline & 7 & 3.30 & 3.48 & 3.39 & 0.12 & 1.06 & 7.4 \\
\hline \multirow[t]{3}{*}{$\mathrm{LSD}_{05}$} & A & 0.03 & 0.14 & & & & \\
\hline & B & 0.08 & 0.07 & & & & \\
\hline & $\mathrm{AB}$ & 0.28 & 0.28 & & & & \\
\hline \multicolumn{8}{|c|}{ Runo emmer wheat (spelt) } \\
\hline \multirow{4}{*}{$\begin{array}{c}\text { Natural } \\
\text { background } \\
\text { (control) }\end{array}$} & 4 & 2.35 & 2.48 & 2.42 & - & - & - \\
\hline & 5 & 2.20 & 2.34 & 2.27 & -0.15 & - & - \\
\hline & 6 & 2.12 & 2.22 & 2.17 & -0.25 & - & - \\
\hline & 7 & 2.03 & 2.10 & 2.20 & -0.22 & - & - \\
\hline \multirow{4}{*}{$\begin{array}{l}\text { NPK estimated } \\
\text { for yielding } 3 \text { tons } \\
\text { of grain per ha }\end{array}$} & 4 & 3.10 & 3.34 & 3.22 & - & 0.80 & 5.6 \\
\hline & 5 & 2.60 & 3.19 & 2.89 & -0.33 & 0.62 & 4.3 \\
\hline & 6 & 2.66 & 2.88 & 2.77 & -0.45 & 0.60 & 4.2 \\
\hline & 7 & 2.51 & 2.73 & 2.62 & -0.60 & 0.42 & 2.9 \\
\hline \multirow[t]{3}{*}{$\mathrm{LSD}_{05}$} & A & 0.16 & 0.17 & & & & \\
\hline & B & 0.24 & 0.11 & & & & \\
\hline & $\mathrm{AB}$ & 0.22 & 0.18 & & & & \\
\hline
\end{tabular}


The study of the elements of the yield structure of both types of wheat showed that the increase in yield on both nutrition backgrounds was determined by the density of the productive plant stand, which was closely dependent on the seeding rate. In soft wheat, a decrease in the density of the productive plant stand with a decrease in seeding rates was not compensated by productive tillering. The maximum yield of soft wheat was obtained by forming the density of the productive plant stand mainly due to the main shoot. Due to the large productive stooling of emmer wheat (spelt) compared to soft wheat, the maximum yield was obtained with a decrease in sowing rates to 4 million germinating grains per hectare (Table 3 ).

At the optimum sowing rate, the productivity of plants of both types of wheat and their density per unit area were in the most favorable combination.
A change in the nutrition background influenced the grain quality of both types of spring wheat. Fertilizers improved the vitreousness of soft wheat by $12.3 \%$, and by $13.6 \%$ for spelt, while the mass fraction of gluten increased by 1.8 and 2.9 , respectively.

Against a fertilized nutrition background, as the seeding rates of the studied wheat species increased from 4 to 7 million, the content of gluten mass fraction in the grain decreased by $1.1-1.2 \%$, its vitreousness decreased by $4.9-5.7 \%$, while the weight of 1000 grains decreased by 3.1-3.8 grams. The best indicators of protein content of $16.3 \%$ were found in spelt in the fertilized variant with a sowing rate of 4 million germinating grains per hectare, while in soft wheat this indicator was only $10.6 \%$ (Table 4).

Table 3. Individual elements of the crop structure of various types of spring wheat at different seeding rates and nutritional background (average over 2018-2019)

\begin{tabular}{|c|c|c|c|c|c|}
\hline $\begin{array}{l}\text { Nutritional } \\
\text { background }\end{array}$ & $\begin{array}{c}\text { Seeding } \\
\text { norm [mln } \\
\text { ha] } \\
\end{array}$ & $\begin{array}{l}\text { Number of plants } \\
\text { per } 1 \mathrm{~m}^{2} \text { (before } \\
\text { harvesting) }\end{array}$ & Productive stooling & $\begin{array}{l}\text { Amount of productive } \\
\text { plant stand per } 1 \mathrm{~m}^{2}\end{array}$ & $\begin{array}{c}\text { Grain mass } \\
\text { from } 1 \text { plant }[\mathrm{g}]\end{array}$ \\
\hline \multirow{5}{*}{$\begin{array}{l}\text { Natural background } \\
\text { (control) }\end{array}$} & \multicolumn{5}{|c|}{ Ulyanovskaya 105 spring soft wheat } \\
\hline & 4 & 292 & 1.15 & 336 & 0.86 \\
\hline & 5 & 350 & 1.10 & 385 & 0.77 \\
\hline & 6 & 396 & 1.05 & 416 & 0.62 \\
\hline & 7 & 441 & 1.0 & 441 & 0.53 \\
\hline \multirow{4}{*}{$\begin{array}{l}\text { NPK estimated for } \\
\text { yielding } 3 \text { tons of } \\
\text { grain per ha }\end{array}$} & 4 & 302 & 1.20 & 362 & 1.1 \\
\hline & 5 & 361 & 1.16 & 419 & 0.92 \\
\hline & 6 & 403 & 1.08 & 435 & 0.89 \\
\hline & 7 & 460 & 1.0 & 460 & 0.75 \\
\hline \multirow{5}{*}{$\begin{array}{l}\text { Natural background } \\
\text { (control) }\end{array}$} & \multicolumn{5}{|c|}{ Runo emmer wheat (spelt) } \\
\hline & 4 & 306 & 2.59 & 793 & 0.82 \\
\hline & 5 & 359 & 2.23 & 800 & 0.65 \\
\hline & 6 & 403 & 2.10 & 846 & 0.55 \\
\hline & 7 & 459 & 1.05 & 757 & 0.49 \\
\hline \multirow{4}{*}{$\begin{array}{l}\text { NPK estimated for } \\
\text { yielding } 3 \text { tons of } \\
\text { grain per ha }\end{array}$} & 4 & 310 & 2.67 & 828 & 1.05 \\
\hline & 5 & 370 & 2.30 & 851 & 0.80 \\
\hline & 6 & 420 & 2.15 & 903 & 0.67 \\
\hline & 7 & 470 & 1.85 & 870 & 0.58 \\
\hline
\end{tabular}

Table 4. Grain quality of spring wheat species at different seeding rates and nutritional background (average over 2018-2019)

\begin{tabular}{|c|c|c|c|c|c|}
\hline $\begin{array}{c}\text { Nutritional } \\
\text { background }\end{array}$ & $\begin{array}{c}\text { Seeding norm } \\
{[\mathrm{mln} \mathrm{ha}]}\end{array}$ & $\begin{array}{c}\text { Mass of } 1000 \\
\text { grains }[\mathrm{g}]\end{array}$ & Vitreousness [\%] & $\begin{array}{c}\text { Mass fraction of gluten } \\
{[\%]}\end{array}$ & Protein content $[\%]$ \\
\hline \multirow{5}{*}{$\begin{array}{c}\text { Natural } \\
\text { background } \\
\text { (control) }\end{array}$} & \multicolumn{5}{|c|}{ Ulyanovskaya 105 spring soft wheat } \\
\hline & 4 & 37.4 & 51.4 & 20.4 & 9.4 \\
\hline & 5 & 36.0 & 52.7 & 20.0 & 9.0 \\
\hline & 6 & 35.2 & 50.0 & 19.5 & 8.7 \\
\hline & 7 & 34.5 & 49.8 & 18.7 & 8.3 \\
\hline \multirow{4}{*}{$\begin{array}{l}\text { NPK estimated } \\
\text { for yielding } 3 \text { tons } \\
\text { of grain per ha }\end{array}$} & 4 & 39.3 & 65.7 & 21.2 & 10.6 \\
\hline & 5 & 38.8 & 62.1 & 21.0 & 10.4 \\
\hline & 6 & 38.2 & 61.7 & 20.4 & 10.0 \\
\hline & 7 & 36.2 & 60.8 & 20.1 & 9.5 \\
\hline \multirow{5}{*}{$\begin{array}{l}\text { Natural } \\
\text { background } \\
\text { (control) }\end{array}$} & \multicolumn{5}{|c|}{ Runo emmer wheat (spelt) } \\
\hline & 4 & 32.4 & 82.4 & 29.2 & 14.2 \\
\hline & 5 & 31.9 & 81.6 & 29.0 & 13.8 \\
\hline & 6 & 30.6 & 80.5 & 28.6 & 13.0 \\
\hline & 7 & 30.0 & 80.0 & 28.0 & 12.6 \\
\hline \multirow{4}{*}{$\begin{array}{l}\text { NPK estimated } \\
\text { for yielding } 3 \text { tons } \\
\text { of grain per ha }\end{array}$} & 4 & 34.6 & 96.0 & 31.3 & 16.3 \\
\hline & 5 & 33.7 & 95.0 & 31.0 & 16.0 \\
\hline & 6 & 32.8 & 93.2 & 30.1 & 15.4 \\
\hline & 7 & 30.8 & 90.3 & 29.9 & 14.9 \\
\hline
\end{tabular}




\section{Conclusion}

On average, over 2 years, the maximum yield of both types of wheat was formed on the background of calculated doses of fertilizers and with an optimal sowing rate of 3.53 tons per hectare for soft wheat and 3.22 tons for spelt.

On the gray forest soil of the Pre-Kama Republic of the Republic of Tatarstan, the highest yield of spring soft wheat of the Ulyanovskaya 105 variety against a natural background is provided by a sowing rate of 5 million grains, against an NPK of 3 tons of grain per ha with 6 million germinating grains per hectare. For the Runo spelt, on both nutrition backgrounds, the highest yield was achieved with a sowing rate of 4 million germinating grains per hectare, which is explained by a large productive stooling.

\section{References}

1. State program "Development of agriculture and regulation of agricultural products, raw materials and food markets in the Republic of Tatarstan for 2013-2020" (Kazan, 2013), 110 p.

2. M.F. Amirov, V.P. Vladimirov, I.M. Serzhanov, F.Sh. Shaikhutdinov, Adaptive technologies of field crops cultivation, monograph (Brig, Kazan, 2018) $124 \mathrm{p}$.
3. The agricultural system of the Republic of Tatarstan. Tradition-based innovation. Part 1. General aspects of the agricultural system, 2rd ed. (Center for Innovative Technologies, Kazan, 2014) $168 \mathrm{p}$.

4. A.V. Artyushchenko, Proc. of the Kustanai Agricult. Experim. Station, 1, 22-29 (1973)

5. M.G. Muslimov, A.B. Ismagilov, Grain Econ. of Russ., 3, 40-42 (2002)

6. S.V. Petrov, I.M. Serzhanov, F.Sh. Shaikhutdinov, Grain Farm of Russ., 6(36), 31-38 (2014)

7. I.P. Talanov, Spring wheat in the forest-steppe of the Volga region (Inter-Graphics, Kazan, 2005) 229 p.

8. E. Suchowilska, M. Wiwart, W. Kandler, M. Sulyok, R. Kriska, J. of the Sci. of Food and Agricult., 90(4), 556-565 (2010)

9. N. Daskalova, S. Doneva, P. Spetsov, Agricult., Ecosyst. and Environ., 178, 78-99 (2013)

10. V. Petrenko, T. Sheiko, R. Spychaj et al. Roman. Agricult. Res., 35, 255-264 (2018)

11. N. Daskalova, S. Doneva, P. Spetsov, Chromosome variation and $H M W$ glutenins in synthetic hexaploid wheats (Triticum turgidum ssp. dicoccum/Aegilops tauschii), Cereal Res. Communicat., 44(3), 453-460 (2016)

12. C.M. Chang, S.G. Bhagwat, A. Gupta, Plant Growth Regulat., 75(1), 89-99 (2014) 